\title{
Applied Entomology and Zoology Vol. 51, No. 2 目次
}

(2016 年 5 月 25 日発行)

\section{REVIEW}

Biodiversity, ecosystem functioning, and classical biological control

E. W. Evans 173

[古典的生物的防除に打ける生物多様性と生態系機能の関係

Edward W. Evans ] 173

\section{ORIGINAL RESEARCH PAPERS}

The clock gene period is essential for the photoperiodic response in the jewel wasp Nasonia vitripennis (Hymenoptera: Pteromalidae)

A. Mukai · S. G. Goto 185

[時計遺伝子 period はキョウソヤドリコバチ Nasonia vitripennis (ハチ目：コガネコバチ科) の光周反応に必須である

向井 歩 $\cdot$ 後藤慎介] 185

Genotyping for the G4946E site of ryanodine receptor gene in Plutella xylostella (Lepidoptera: Yponomeutidae) considering gene duplication

S. Sonoda $\cdot$ Y. Kataoka 195

[遺伝子重複を考虑したコナガ Plutella xylostella（チョウ目：スガ

科) のリアノジン受容体遺伝子 G4946E 部位のジェノタイピング

園田昌司・片岡洋子］ 195

Reproductive behavior of the masson pine caterpillar, Dendrolimus punctatus (Lepidoptera: Lasiocampidae) under laboratory conditions

K.-N. Zhou - S.-Y. Zhang - J.-P. Zeng - D. Luo - X.-P. Liu 205

[実験室内におけるカレハガ科の一種 Dendrolimus punctatus（チョ ウ目：カレハガ科) の生殖行動

Kang-Nian Zhou $\cdot$ Shi-Yu Zhang $\cdot$ Ju-Ping Zeng $\cdot$ Dan Luo $\cdot$ XingPing Liu] 205

Isolation, characterization and virulence of entomopathogenic fungi from Gryllotalpa gryllotalpa (Orthoptera: Gryllotalpidae)

E. Sönmez • A. Sevim • Z. Demirbağ • İ. Demir 213

[ケラ科の一種 Gryllotalpa gryllotalpa (バッタ目：ケラ科) から分 離した昆虫病原性糸状菌の系統，特性及び病原性

Emine Sönmez $\cdot$ Ali Sevim • Zihni Demirbağ $\cdot$ İsmail Demir $] 213$
Functional characterization of the corazonin-encoding gene in phase polyphenism of the migratory locust, Locusta migratoria (Orthoptera: Acrididae)

R. Sugahara $\cdot$ S. Tanaka • A. Jouraku ・ T. Shiotsuki 225

[トノサマバッタ Locusta migratoria (バッタ目：バッタ科) 相変異

におけるコラゾニン遺伝子の機能

管原亮平・田中誠二・上樂明也・塩月孝博 $] 225$

A simple plant trap for collecting acariphagous insect predators and their parasitoids

T. Shimoda $\cdot$ K. Matsuo $\cdot$ K. Yara $\cdot$ N. Hinomoto 233

[八ダニ捕食性昆虫類およびその捕食寄生蜂を採集するための簡

易植物トラップ

下田武志・松尾和典・屋良佳緒利・日本典秀］ 233

Attraction of males of the cupreous polished chafer Protaetia pryeri pryeri (Coleoptera: Scarabaeidae) for pollination by an epiphytic orchid Luisia teres (Asparagales: Orchidaceae)

N. Arakaki $\cdot$ K. Yasuda $\cdot$ S. Kanayama $\cdot$ S. Jitsuno $\cdot$ M. Oike $\cdot$ S. Wakamura 241

[ボウラン Luisia teres（キジカクシ目：ラン科）は受粉のために リュウキュウツヤハナムグリ Protaetia pryeri pryeri (コウチュウ 目：コガネムシ科) の雄成虫を誘引する

新垣則雄 · 安田慶次 · 金山祥子 · 實野早紀子 · 大池昌裕 - 若村定 男] 241

Evaluation of the demographic potential of Aphelinus albipodus (Hymenoptera: Aphelinidae) with Aphis glycines (Homoptera: Aphididae) as alternate host at various temperatures

X. Wang $\cdot$ Y. Song $\cdot$ H. Sun $\cdot$ J. Zhu 247

[ダイズアブラムシ Aphis glycines（カメムシ目：アブラムシ科）を 代替餌として用いたツヤコバチ科の一種Aphelinus albipodus（ハ チ目：ツヤコバチ科) のさまざまな温度条件下に打ける生活史特 性の評価

Xiaodong Wang · Yueqin Song · Huizhong Sun · Jinfeng Zhu 247

Interaction between Bactrocera oleae (Diptera: Tephritidae) infestation and fruit mineral element content in Olea europaea (Lamiales: Oleaceae) cultivars of global interest N. Garantonakis · K. Varikou • E. Markakis · A. Birouraki · C. Sergentani • G. Psarras • G. C. Koubouris 257 
[欧州に分布するオリーブ Olea europaea (シソ目：モクセイ科) 品種間に抢けるミバエ科の一種 Bactrocera oleae (ハエ目：ミバエ 科) の寄生と果実のミネラル構成成分との相互関係

Nikos Garantonakis - Kyriaki Varikou Emmanouil Markakis • Athanasia Birouraki $\cdot$ Chrysa Sergentani $\cdot$ Georgios Psarras $\cdot$ Georgios C. Koubouris ] 257

Reducing damage caused by oak wilt disease transmitted by the ambrosia beetle Platypus quercivorus (Coleoptera: Platypodidae) using oak log pile traps

S. Saito $\cdot$ H. Kondoh $\cdot$ A. Takahashi $\cdot$ M. Okada $\cdot$ H. Miguchi $\mathbf{2 6 7}$

[ナラの集積した丸太トラップによるナラ枯れを伝播するカシノ ナガキクイムシ Platypus quercivorus (コウチュウ目：ナガキクイ ムシ科) の被害軽減

斉藤正一 - 近藤洋史 ·高橋 文・岡田充弘 箕口秀夫 $] 267$

Redescriptions and distributions of acarivorous rove beetles, Holobus kashmiricus beneficus and $H$. yasumatsui (Coleoptera: Staphylinidae: Aleocharinae), in Japan and Taiwan

T. Kanao ・ M. Maruyama $\cdot$ S. Ohno 275

[ハダニを専食するヒメハダニカブリケシハネカクシ Holobus kashmiricus beneficus とハダニカブリケシハネカクシ H. yasumatsui (コウチュウ目：ハネカクシ科：ヒゲブトハネカクシ亜科)の再記 載および日本と台湾に打ける分布

金尾太輔・ 丸山宗利・大野 豪] 275

Specialization and host plant use of the common clones of Sitobion avenae (Homoptera: Aphididae)

H. Alkhedir - P. Karlovsky · A. M. A. Mashaly 'S. Vidal $\mathbf{2 8 9}$

[アブラムシ科の一種 Sitobion avenae (カメムシ目:アブラムシ科) の優占クローンの分化と寄主植物利用

Hussein Alkhedir • Petr Karlovsky • Ashraf Mohemed Ali Mashaly • Stefan Vidal] 289

Differences in the reproductive durations of Myzus persicae (Hemiptera: Aphididae) parasitized by three aphidiid parasitoids

T. Mitsunaga $\cdot$ K. Nagasaka $\cdot$ S. Moriya 297

[3 種のアブラバチ類に寄生されたモモアカアブラムシ Myzus persicae (カメムシ目 : アブラムシ科)の産仔可能期間の違いについて 光永貴之・長坂幸吉・守屋成一］ 297
Baculoviral IAP2 and IAP3 encoded by Lymantria xylina multiple nucleopolyhedrovirus (LyxyMNPV) suppress insect cell apoptosis in a transient expression assay Y.-S. Nai • Y.-T. Yang • J. S. Kim • C.-Y. Wu • Y.-W. Chen · C.-H. Wang 305

[ドクガ科の一種Lymantria xylinaの核多角体病ウイルス (LyxMNPV) にコードされるバキュロウイルス由来の IAP2 と IAP3 は一過性発 現アッセイにおいて昆虫細胞死を抑制する

Yu-Shin Nai $\cdot$ Yi-Ting Yang $\cdot \mathrm{Jae} \mathrm{Su} \mathrm{Kim} \cdot$ Chih-Yu Wu $\cdot$ Yue-Wen Chen $\cdot$ Chung-Hsiung Wang] 305

\section{TECHNICAL NOTES}

Isolation and characterization of 13 polymorphic microsatellite loci for the fig wasp, Ceratosolen sp. (Hymenoptera: Agaonidae)

L. Tan · J.-Y. Deng • R.-H. Fu • Y. Chen 317

[イチジクコバチ科の一種 Ceratosolen sp. (ハチ目：イチジクコバ チ科)に扎いて新規に開発した 13 個の多型マイクロサイト遺伝子 座の特徵

Lu Tan · Jun-Yin Deng $\cdot$ Rong-Hua Fu $\cdot$ Yan Chen $] 317$

Rearing Orius strigicollis (Hemiptera: Anthocoridae) on an alternative diet of brine shrimp, Artemia salina (Anostraca: Artemiidae)

T. Nishimori $・$ K. Miura ・ T. Seko 321

[代替餌ブラインシュリンプ Artemia salina（ホウネンエビ目：ホ ウネンエビモドキ科) でのタイリクヒメハナカメムシ Orius strigicollis (カメムシ目：ハナカメムシ科) の飼育

西森敬晃・三浦一芸・世古智一］ 321

Development of microsatellite markers for the plant bug, Pachypeltis micranthus (Hemiptera: Miridae)

J.-Y. Zhu • S.-Z. Ze • L.-J. Cao • B. Yang 327

[カスミカメムシ科の一種 Pachypeltis micranthus（カメムシ目：カ スミカメムシ科) に打けるミクロサテライトマーカーの開発 Jia-Ying Zhu $\cdot$ Sang-Zi Ze $\cdot$ Li-Jun Cao $\cdot$ Bin Yang] 327

Within-greenhouse and within-plant distribution of greenhouse whitefly, Trialeurodes vaporariorum (Hemiptera: Aleyrodidae), in strawberry greenhouses

M. S. Ullah • U. T. Lim 333

[イチゴ温室に生息するオンシッコナジラミ Trialeurodes vaporariorum (カメムシ目 : コナジラミ科) の温室内と植物内に打ける分布

Mohammad Shaef Ullah • Un Taek Lim ] 333 